\title{
Francis Gingras, Le livre arthurien et la matière du roman
}

\section{Maria Colombo Timelli}

\section{(2) OpenEdition}

1 Journals

Édition électronique

URL : http://journals.openedition.org/studifrancesi/3642

DOI : 10.4000/studifrancesi.3642

ISSN : 2427-5856

Éditeur

Rosenberg \& Sellier

\section{Édition imprimée}

Date de publication : 1 décembre 2012

Pagination : 542

ISSN : 0039-2944

\section{Référence électronique}

Maria Colombo Timelli, « Francis Gingras, Le livre arthurien et la matière du roman », Studi Francesi [En ligne], 168 (LVI | III) | 2012, mis en ligne le 30 novembre 2015, consulté le 07 mars 2021. URL : http:// journals.openedition.org/studifrancesi/3642 ; DOI : https://doi.org/10.4000/studifrancesi.3642

Ce document a été généré automatiquement le 7 mars 2021.

\section{(c) $(1) \&$}

Studi Francesi è distribuita con Licenza Creative Commons Attribuzione - Non commerciale - Non opere derivate 4.0 Internazionale. 


\title{
Francis Gingras, Le livre arthurien et la matière du roman
}

\author{
Maria Colombo Timelli
}

\section{RÉFÉRENCE}

FRANCIS GINGRAS, Le livre arthurien et la matière du roman, «Bulletin Bibliographique de la Société Internationale Arthurienne», LXII, 2010, pp. 277-306.

Dans le cadre de ses recherches sur l'histoire du roman français dans la longue durée, Francis Gingras a exposé, lors d'une conférence plénière au Congrès Arthurien de Rennes (juillet 2008), une réflexion de très grand intérêt qui porte sur le rapport entre matière romanesque-arthurienne, en l'occurrence-et livre, objet destiné à transmettre une matière donnée: c'est le texte de cette importante contribution qui est publié ici. Ses remarques portent sur la «mise en recueil», qui a touché tout particulièrement le Conte du Graal de Chrétien et ses Continuations et pseudo-prologues; puis sur l'organisation du «livre arthurien» en livres et/ou en volumes, et sur sa structure interne, en chapitres ou en branches. Une dernière section est consacrée aux lecteurs des manuscrits arthuriens, au prix des volumes et à leur présence dans les bibliothèques des $\mathrm{XIII}^{\mathrm{e}}$-XVI ${ }^{\mathrm{e}}$ siècles. 